\title{
The Swift Surge of Perovskite Photovoltaics
}

7 he breakthrough early 1990s dye sensitization of 1 mesoscopic $\mathrm{TiO}_{2}$ films along with a regenerative iodide redox couple led to the explosive growth of dye-sensitized solar cell (DSC) research. The pioneering work of Grätzel and colleagues also made it possible to develop a solid-state DSSC with spiro-oMETAD as the hole conductor and thus replace the liquid electrolyte in the cell. Research efforts of Konenkamp and others further initiated the search for the "extremely thin absorber" (ETA) nanostructured solar cell, using $\mathrm{TiO}_{2}$ as the electron conductor, an inorganic absorber, and a hole conductor. Another major research thrust was by Weller, Kamat, Zaban, Nozik, Hodes, and others, who employed inorganic quantum dots (e.g., CdS and CdSe) as sensitizers. While discussing developments in sensitized solar cells, it is important to note the contributions of early visionaries like Gerischer, Sutin, and Bard, who were first to establish the concepts of sensitization using dye molecules and semiconductor nanostructures.

The efforts to develop solid-state solar cells initiated effervescent activity around 2010 when efficiencies of 5\% were attained with $\mathrm{Sb}_{2} \mathrm{~S}_{3}$ inorganic sensitizers and organic hole conductors. However, the efficiencies of inorganic semiconductor-sensitized solar cells lagged behind those achieved with the liquid junction DSCs. This stalemate took a major leap in late 2012 when a relatively less known organometal halide perovskite, $\mathrm{CH}_{3} \mathrm{NH}_{3} \mathrm{PbI}_{3}$ (Figure 1), emerged as the light

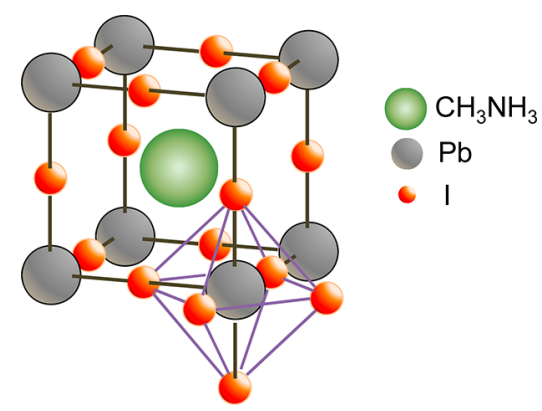

Figure 1. Structure of $\mathrm{CH}_{3} \mathrm{NH}_{3} \mathrm{PbI}_{3}$ perovskite (reproduced with permission from J. Phys. Chem. Lett., (Park, 2013)).

\section{Recent reports of efficiencies of $12-15 \%$ have led to make the bold prediction of the "Next Big Thing in Photovoltaics".}

harvester delivering efficiencies about $10 \%$. Recent reports of efficiencies of $12-15 \%$ have led to make the bold prediction of the "Next Big Thing in Photovoltaics". The rise of the perovskite solar cell started with the initial report of Miyasaka's group, which went unnoticed until the work of Nam-Gyu Park, Grätzel, and co-workers reported a power conversion efficiency exceeding 9\% and a report of Snaith's group achieving efficiencies of $10 \%$ appeared. By replacing $\mathrm{TiO}_{2}$ with an $\mathrm{Al}_{2} \mathrm{O}_{3}$ mesostructure, it was possible to demonstrate the ambipolar property of the perovskite material. Further refinements in the materials processing and cell design have now led to the success of achieving certified efficiencies of $14 \%$.

These highly efficient pervoskite solar cells have brought new enthusiasm to develop efficient thin film hybrid photovoltaics.

\section{These highly efficient pervoskite solar cells have brought new enthusiasm to develop efficient thin film hybrid photovoltaics.}

Nam-Gyu Park, who has been at the center of perovskite solar cell research, has now presented the evolution of the field, explaining how the efficiencies have raised from the point of view of materials design to device making. His perspective in this issue of J. Phys. Chem. Lett. discusses the crucial details of the perovskite solar cell components, the different configurations, and the properties of the absorber. By analyzing feasible development of the photocurrent and photovoltage, attaining perovskite solar cells with $20 \%$ efficiency may be reached in the near future. Basic understanding of the excitedstate dynamics, charge separation, and charge transport in these thin films will be the key in achieving this goal. A few early investigations addressing the issues of high open-circuit voltage and the effect of hole conductors already appeared in the earlier issues of J. Phys. Chem. Lett. It is certain that many new research efforts and technological advances related to pervoskite will dominate in the coming years.

Juan Bisquert, Senior Editor, The Journal of Physical Chemistry $A / B / C$

Universitat Jaume I, Castelló, Spain

\section{AUTHOR INFORMATION}

\section{Notes}

Views expressed in this Editorial are those of the author and not necessarily the views of the ACS.

\section{RELATED READINGS}

(1) Park, N.-G. Organometal Perovskite Light Absorbers. Toward 20\% Efficiency Low-Cost Solid-State Mesoscopic Solar Cell. J. Phys. Chem. Lett. 2013, 4, 2423-2429.

(2) O’Regan, B.; Graetzel, M. A Low-Cost, High-Efficiency Solar Cell Based on Dye-Sensitized Colloidal $\mathrm{TiO}_{2}$ Films. Nature 1991, 353, 737-740.

(3) Bach, U.; Lupo, D.; Comte, P.; Moser, J. E.; Weissortel, F.; Salbeck, J.; Spreitzer, H.; Gratzel, M. Solid-State Dye-Sensitized Mesoporous $\mathrm{TiO}_{2}$ Solar Cells with High Photon-to-Electron Conversion Efficiencies. Nature 1998, 395, 583-585.

Published: August 1, 2013 
(4) Kaiser, I.; Ernst, K.; Fischer, C. H.; Konenkamp, R.; Rost, C.; Sieber, I.; Lux-Steiner, M. C. The ETA-Solar Cell with $\mathrm{CuInS}_{2}$ : A Photovoltaic Cell Concept Using an Extremely Thin Absorber (ETA). Solar Energy Mater. Solar Cells 2001, 67, 89-96.

(5) Vogel, R.; Pohl, K.; Weller, H. Sensitization of Highly Porous, Polycrystalline $\mathrm{TiO}_{2}$ Electrodes by Quantum Sized CdS. Chem. Phys. Lett. 1990, 174, 241-246.

(6) Hotchandani, S.; Kamat, P. V. Charge-Transfer Processes in Coupled Semiconductor Systems. Photochemistry and Photoelectrochemistry of the Colloidal CdS-ZnO System. J. Phys. Chem. 1992, 96, 6834-6839.

(7) Robel, I.; Subramanian, V.; Kuno, M.; Kamat, P. V. Quantum Dot Solar Cells. Harvesting Light Energy with CdSe Nanocrystals Molecularly Linked to Mesoscopic $\mathrm{TiO}_{2}$ Films. J. Am. Chem. Soc. 2006, 128, 2385-2393.

(8) Zaban, A.; Micic, O. I.; Gregg, B. A.; Nozik, A. J. Photosensitization of Nanoporous $\mathrm{TiO}_{2}$ Electrodes with InP Quantum Dots. Langmuir 1998, 14, 3153-3156.

(9) Nozik, A. J. Quantum Dot Solar Cells. Physica E 2002, 14, 115120.

(10) Hodes, G.; Howell, I. D. J.; Peter, L. M. Nanocrystalline Photoelectrochemical Cells. A New Concept in Photovoltaic Cells. J. Electrochem. Soc. 1992, 139, 3136-3140.

(11) Gerischer, H. Electrochemical Techniques for the Study of Photosensitization. Photochem. Photobiol. 1972, 16, 243-260.

(12) Gerischer, H.; Willig, F. Reaction of Excited Dye Molecules at Electrodes. Top. Curr. Chem. 1976, 61, 31-84.

(13) Gerischer, H.; Luebke, M. A Particle Size Effect in the Sensitization of $\mathrm{TiO}_{2}$ Electrodes by a CdS Deposit. J. Electroanal. Chem. 1986, 204, 225-227.

(14) Clark, W. D. K.; Sutin, N. Spectral Sensitization of n-Type $\mathrm{TiO}_{2}$ Electrodes by Polypyridineruthenium(II) Complexes. J. Am. Chem. Soc. 1977, 99, 4676-4682.

(15) Jaeger, C. D.; Fan, F. R. F.; Bard, A. J. Semiconductor Electrodes. 26. Spectral Sensitization of Semiconductors with Phthalocyanine. J. Am. Chem. Soc. 1980, 102, 2592-2598.

(16) Moon, S.-J.; Itzhaik, Y.; Yum, J.-H.; Zakeeruddin, S. M.; Hodes, G.; Gratzel, M. $\mathrm{Sb}_{2} \mathrm{~S}_{3}$-Based Mesoscopic Solar Cell Using an Organic Hole Conductor. J. Phys. Chem. Lett. 2010, 1, 1524-1527.

(17) Chang, J. A.; Rhee, J. H.; Im, S. H.; Lee, Y. H.; Kim, H.-J.; Seok, S. I.; Nazeeruddin, M. K.; Gratzel, M. High-Performance Nanostructured Inorganic-Organic Heterojunction Solar Cells. Nano Lett. 2010, 10, 2609-2612.

(18) Kim, H. S.; Lee, C. R.; Im, J. H.; Lee, K. B.; Moehl, T.; Marchioro, A.; Moon, S. J.; Humphry-Baker, R.; Yum, J. H.; Moser, J. E. Lead Iodide Perovskite Sensitized All-Solid-State Submicron Thin Film Mesoscopic Solar Cell with Efficiency Exceeding 9\%. Sci. Rep. 2012, 2, 591.

(19) Lee, M. M.; Teuscher, J.; Miyasaka, T.; Murakami, T. N.; Snaith, H. J. Efficient Hybrid Solar Cells Based on Meso-Superstructured Organometal Halide Perovskites. Science 2012, 338, 643-647.

(20) Noh, J. H.; Im, S. H.; Heo, J. H.; Mandal, T. N.; Seok, S. I. Chemical Management for Colorful, Efficient, and Stable InorganicOrganic Hybrid Nanostructured Solar Cells. Nano Lett. 2013, 13, 1764-1769.

(21) Burschka, J.; Pellet, N.; Moon, S.-J.; Humphry-Baker, R.; Gao, P.; Nazeeruddin, M. K.; Gratzel, M. Sequential Deposition As a Route to High-Performance Perovskite-Sensitized Solar Cells. Nature 2013, 499, 316-319.

(22) Kamat, P. V. Quantum Dot Solar Cells. The Next Big Thing in Photovoltaics. J. Phys. Chem. Lett. 2013, 4, 908-918.

(23) Kojima, A.; Teshima, K.; Shirai, Y.; Miyasaka, T. Organometal Halide Perovskites as Visible-Light Sensitizers for Photovoltaic Cells. J. Am. Chem. Soc. 2009, 131, 6050-6051.

(24) Edri, E.; Kirmayer, S.; Cahen, D.; Hodes, G. High Open-Circuit Voltage Solar Cells Based on Organic-Inorganic Lead Bromide Perovskite. J. Phys. Chem. Lett. 2013, 4, 897-902.

(25) Bi, D.; Yang, L.; Boschloo, G.; Hagfeldt, A.; Johansson, E. M. J. Effect of Different Hole Transport Materials on Recombination in
$\mathrm{CH}_{3} \mathrm{NH}_{3} \mathrm{PbI}_{3}$ Perovskite-Sensitized Mesoscopic Solar Cells. J. Phys. Chem. Lett. 2013, 4, 1532-1536.

(26) Burschka, J.; Pellet, N.; Moon, S.-J.; Humphry-Baker, R.; Gao, P.; Nazeeruddin, M. K.; Grätzel, M. Sequential deposition as a route to high-performance perovskite-sensitized solar cells. Nature 2013, 499, 316-319. 